\title{
O CONCEITO DE FETICHISMO NA OBRA MARXIANA: UMA TENTATIVA DE INTERPRETAÇÃO
}

\author{
THE CONCEPT OF FETISHISM IN MARXIAN'S WORK: \\ AN ATTEMPT TO INTERPRETATION
}

\author{
AMARO FLECK ${ }^{1}$ \\ (UFSC / Brasil)
}

\begin{abstract}
RESUMO
No presente artigo busco oferecer uma análise interpretativa do conceito de fetichismo (da mercadoria, do dinheiro e do capital) na obra marxiana. Para tanto, delineio, sucintamente, a gênese histórica dos termos fetiche e fetichismo (I), para, em seguida, demonstrar que Marx inverte o uso deste conceito, de tal maneira que ele não mais se refere ao "outro", mas, ao contrário, designa algo da própria modernidade capitalista com este conceito (II). Analiso, posteriormente, as aparições do termo nas obras anteriores a $O$ Capital e em $O$ Capital (III), visando mostrar que o conceito de fetichismo, em Marx, está sempre ligado a um fenômeno de transubstanciação (do trabalho já realizado na mercadoria) e que os objetos fetiche diferenciam-se dos demais por sempre possuírem uma "dupla existência". A seguir, examino a semelhança do capitalismo com as religiões como formas de "opacidade" social, como formas de encantamento do mundo, encantamento este que impede a criação de uma situação racional e justa (IV). Concluo o artigo com uma breve análise de como seria possível superar, segundo Marx, o fetichismo, isto é, dizer no que consistiria uma sociedade não fetichista.
\end{abstract}

Palavras-chave: Fetichismo. O Capital. Karl Marx. Crítica da modernidade. Crítica do capitalismo. Teoria do valor.

\begin{abstract}
In this paper, I try to offer an interpretative analysis of the concept of fetishism (of commodity, of money and of capital) in Marx's work. To this end, I outline the historical genesis of the words fetish and fetishism (I), in order to show, in the sequence, that Marx reverses the use of these concepts, so that he doesn't refer to the "other", but, on the contrary, in order to designate something essential to capitalist modernity (II). I examine, furthermore, the appearance of this concept both before and in Capital (III), with the aim to show that the concept of fetishism in Marx's work is always bound with the phenomenon of transubstantiation (of work always present in the commodity) and that the object fetish distinguishes itself from others because it always has a "double existence". In the sequence, I analyze the resemblance of the capitalism to religion as forms of social "opacity", as ways of enchantment of the world, an enchantment that prevents the creation of a just and rational situation (IV). I conclude my article with a succinct analysis of how it would be possible, according to Marx, to overcome the fetishism, i.e., in an analysis of what a non-fetishist society would be.
\end{abstract}

Keywords: Fetishism. Capital. Karl Marx. Critique to modernity. Critique to capitalism. Value's theory.

A análise do fetichismo da mercadoria, parte concluinte do primeiro capítulo de $O$ Capital, é um dos momentos mais enigmáticos da obra madura marxiana e, exatamente por isto, 
requer um grande esforço interpretativo. Este esforço, contudo, não deve ser prorrogado, tal como sugere Althusser, ${ }^{2}$ mas enfrentado desde o primeiro momento, uma vez que o conceito de fetichismo ocupa um lugar central na arquitetônica da obra e é de fundamental importância para a correta interpretação da crítica de Marx ao modo capitalista de organização social. O enigma que envolve o conceito de fetichismo na obra marxiana decorre claramente da sua utilização em um livro que trata, principalmente, da forma de organização econômica das sociedades desenvolvidas, e não, como seria de se esperar, de formas de religião ditas primitivas, de análises de mitologia ou ainda de formas de pensamento.

$\mathrm{Na}$ vasta literatura de comentários à obra marxiana, sobretudo naqueles dedicados à fase tardia e à análise do capitalismo, o tema do fetichismo está quase sempre presente. Contudo, são muito poucas as interpretações que dão conta de responder a questões tais como: Porque a mercadoria é fetichista? Qual a relevância do conceito de fetichismo na argumentação de $O$ Capital? Como este conceito se relaciona, caso se relacione, com o restante da obra? Por fim, em que é modificado o diagnóstico da modernidade apresentado pelo autor com a introdução, nas obras tardias, da teoria do fetichismo $?^{3}$ Em geral, o tema do fetichismo é tratado em separado, algo como um excerto aparte da argumentação geral da obra, uma excrescência que poderia, muito bem, não estar aí. No mais das vezes o conceito de fetichismo é reduzido ao fato de que a economia política clássica naturaliza relações historicamente determinadas, de modo que as torna inquestionáveis; ou seja, o fetichismo é compreendido de maneira similar ao termo "robinsonada", 4 tendo um sentido metafórico, distinto do usual. ${ }^{5}$ Minha intenção aqui é demonstrar que o uso marxiano do termo não é distinto do sentido usual deste, ao menos não em termos de significado (isto é, Marx, com o termo fetichismo, busca mostrar uma semelhança que une o capitalismo com determinadas crenças mítico-religiosas); assim como apontar para a crucial importância deste termo na argumentação acerca do capital, de tal maneira que sua análise é imprescindível para se compreender a crítica marxiana ao capitalismo e à modernidade.

O presente artigo começa com a análise do uso pré-marxiano do conceito de fetichismo (I), para, em seguida, mostrar como Marx "inverte" sua utilização (mas não seu significado) original (II). Posteriormente examina-se o papel deste conceito nas obras anteriores a $O$ Capital, nas quais, grosso modo, pode-se dizer que a teoria do fetichismo ainda não está plenamente desenvolvida; na sequência, analisa-se o uso do conceito de fetichismo no desenvolvimento do argumento marxiano em $O$ Capital (III) e a crítica à prática mercantil capitalista como uma 
espécie sui generis de prática supersticiosa, fetichista (IV). A conclusão trata da possibilidade de superação do fetichismo, que é, concomitantemente, a abolição do capitalismo; ou melhor, buscase esboçar, sucintamente, aquilo que seria uma sociedade não fetichista, algo que coincide, ao menos em Marx, com aquilo que poderia ser chamado de sociedade comunista.

\section{I. $O$ conceito de fetichismo antes de Marx}

A palavra "fetichismo" deriva de "fetiche". "Fetiche", em português, deriva da palavra francesa "fétiche", a qual, por sua vez, tem sua origem na portuguesa "feitiço". Esta última, por fim, remete à latina "facticius", significando aproximadamente o mesmo que "artificial". O dicionário Le Petit Robert enumera três significados para "fétiche": "1. Nome dado pelos brancos aos objetos de culto das civilizações ditas primitivas", "2. Objeto ao qual se atribui um poder mágico ou benéfico" e "3. Aquilo que é reverenciado sem discernimento".

Alfonso Iacono, ao relatar a história do surgimento do conceito de fetichismo, conta que tal conceito aparece pela primeira vez em um ensaio de Charles de Brosses, em 1756, intitulado Histoire des navigations aux terres australes, e será mais desenvolvido pelo mesmo autor quatro anos depois, em Du culte des dieux fétiches (cf. Iacono, 1992). Na obra de De Brosses, o conceito de fetichismo está imbricado com uma teoria geral da religião dos povos ditos selvagens e primitivos, assim como a uma teoria geral do progresso do pensamento humano, progresso este que conduz do estágio inicial onde estão os negros africanos adoradores de fetiches até os civilizados e esclarecidos europeus. A ideia subjacente é a de uma progressão linear na qual o objeto sagrado é tornado cada vez mais abstrato: começa-se com a divinificação de objetos materiais (fetichismo), segue-se com uma multiplicidade de deuses que se imiscuem na vida humana (politeísmo) e finda-se com um deus único, criador e julgador, mas que, grosso modo, deixa os problemas humanos seguirem seu próprio curso. Destarte, o progresso do pensamento humano iria do concreto ao abstrato, e o fetichismo seria a primeira tentativa de explicar os fenômenos da natureza através da crença em qualidades mágicas de determinados objetos.

O próprio De Brosses já faz uma clara definição do termo: “[a expressão fetichismo] está ligada particularmente à crença dos negros da África, mas a utilizo igualmente para falar de qualquer outra nação nas quais os objetos de culto são os animais, ou os seres inanimados, que se divinizam", estes objetos não necessitam ser os próprios deuses, podem ser simplesmente "coisas 
dotadas de uma virtude divina, os oráculos, os amuletos, os talismãs preservativos" (De Brosses, apud Iacono, 1992, p. 69). Fetichismo é a crença de que certos animais ou coisas inanimadas são dotados de qualidades sobrenaturais, divinas.

É com o sentido que lhe dá De Brosses, como atesta o verbete do dicionário supracitado, que o termo se cristaliza. É um termo que foi criado para se referir ao "outro", ao "não civilizado", ao "bárbaro", àquele que ainda não pensa cientificamente, corretamente, logicamente. É tal uso que Marx subverte quando utiliza o conceito de fetichismo não para se referir aos negros da Guiné adoradores de talismãs, mas sim aos brancos europeus trocadores de mercadorias.

\section{O fetichismo às avessas}

Há, sem sombra de dúvida, um golpe retórico na utilização do termo "fetichismo" por Marx. Este autor se apropria de um conceito, que antes fora usado para designar o outro, de forma reflexiva, isto é, não para designar o alheio mas sim para explicar a sua própria sociedade, ou melhor, o modo pelo qual os homens se relacionam nas sociedades onde impera o modo capitalista de produção. ${ }^{6} \mathrm{O}$ uso reflexivo abole, em primeira instância, a distinção rígida entre o civilizado e o primitivo, mostrando, neste caso específico, o quanto de primitivo há no civilizado. Mas esta não é uma crítica que visa mostrar que "todas as vacas são pardas"; tal conclusão, como em Hegel, só aponta para o fato de se estar na "noite do pensamento". As diferenças não são abolidas em prol de uma igualação na barbárie. Apontar para um elemento fetichista na sociedade pretensamente civilizada visa corrigir uma visão deformada do mundo, conduzir o indivíduo que afirma a superioridade da sua sociedade a uma posição na qual ele mesmo é obrigado a criticá-la radicalmente. O objetivo não é a igualação mas a superação. Criar uma sociedade civilizada, tornar a sociedade pretensamente esclarecida em uma sociedade esclarecida de fato. Mas, para isto, reconhecer o entrelaçamento do fetichismo na civilização é somente o primeiro passo.

Notar que em Marx há elementos retóricos não é o mesmo que dizer que o uso do conceito de fetichismo por ele é unicamente retórico. $\mathrm{O}$ argumento não teria a força que possui se Marx não apontasse para uma identidade profunda que une a prática da troca de mercadorias à adoração de objetos inanimados, tal como será analisado nas seções seguintes. Antes de Marx, a crítica usual ao esclarecimento e a modernidade é àquela dos românticos, crítica esta que visa, 
quase sempre, ao retorno a um passado idílico, harmônico. ${ }^{7}$ Os pensadores comprometidos com o esclarecimento, grosso modo, afirmam-no sem ressalvas: os problemas do mundo decorrem do fato de o processo do esclarecimento ainda estar incompleto, inconcluso. Marx cria uma nova posição ao criticar a modernidade rechaçando o romantismo. ${ }^{8}$ Para ele, a própria modernidade possui elementos fetichistas, elementos estes que impedem a efetivação do próprio esclarecimento. A modernidade possui assim um caráter antagônico: tem um imenso potencial emancipatório, libertador, mas também mecanismos repressivos que impedem a efetivação da emancipação. Trata-se, portanto, de criticar a modernidade e o esclarecimento a partir da própria modernidade e esclarecimento, de uma crítica imanente voltada ao futuro.

\section{Do fetichismo da mercadoria ao fetichismo do capital}

As aparições do conceito antes de "O Capital"

O conceito de fetichismo já aparecera algumas vezes na obra de Marx antes da célebre seção sobre o fetichismo da mercadoria. Já em 1842, nos artigos escritos na Rheinische Zeitung, o jovem Marx se refere um par de vezes a este conceito, uma vez, inclusive, com o modo reflexivo que o caracteriza, ao dizer que "os selvagens de cuba consideravam o ouro o fetiche dos hispânicos" (Marx, 1842, s.p.). Nos manuscritos parisienses de 1844 o termo aparece outro par de vezes, sendo uma delas como sinônimo de católico. Mas é preciso esperar por mais de uma década para que o termo, que então aparece simplesmente como um adjetivo geral, ganhe uma conotação bastante específica, um sentido preciso, uma teoria própria.

Nos Grundrisse, os cadernos de esboços que Marx escreveu ao longo de 1857 e 1858, o conceito já aparece, embora ainda de maneira bastante precária frente ao uso que terá em $O$ Capital, cito-o:

\footnotetext{
O materialismo tosco dos economistas, de considerar como qualidades naturais das coisas as relações sociais de produção dos seres humanos e as determinações que as coisas recebem, enquanto subsumidas a tais relações, é um idealismo igualmente tosco, um fetichismo que atribui às coisas relações sociais como determinações que lhe são imanentes e, assim, as mistifica. (Marx, 2011, 575)
}

Nesta citação dos Grundrisse, o termo fetichismo já aparece no sentido usual da obra tardia marxiana, a saber, referindo-se ao fato de que são atribuídas relações sociais às coisas. Porém, 
neste trecho, o fetichismo está no "materialismo tosco dos economistas" (materialismo este que é também uma forma de idealismo), sendo simplesmente um erro de consciência que acaba por mistificar o objeto estudado, e não, como em $O$ Capital, uma propriedade do próprio objeto. Trata-se, então, de uma confusão na consciência entre aquilo que são as qualidades naturais das coisas e aquilo que são relações sociais de produção, de tal maneira que estes economistas naturalizam (e, portanto, eternalizam, deshistoricizam) relações historicamente determinadas, configurações sociais específicas.

Em Para a crítica da economia política o termo aparecerá novamente: "a natureza não produz dinheiro, nem tampouco banqueiros ou cotação da moeda. Mas como a produção burguesa necessita cristalizar a riqueza como fetiche, na forma de uma única coisa, o ouro e a prata tornam-se essa encarnação correspondente" (Marx, 1982, p 111-112). Nesta citação, embora ainda bastante vaga, o termo já ganha outra conotação. Não mais se refere a uma postura subjetiva do economista, a uma confusão na consciência, mas sim a uma necessidade objetiva da própria produção burguesa, a saber, a necessidade de cristalizar a riqueza em um objeto particular $^{9}$ (que se tornará, deste modo, o meio de troca).

Nas Teorias da mais-valia, texto escrito em 1861, o termo fetichismo aparecerá diversas vezes, sendo utilizado nos dois sentidos acima referidos, isto é, tanto para se referir a uma confusão na consciência de alguns economistas, quanto a uma propriedade objetiva do processo capitalista. O trecho, a meu ver, mais importante, é um excerto no qual Marx fala do capital portador de juros:

A ossificação das relações, a apresentação delas como a relação de homens com coisas tendo um caráter social determinado, é aqui elaborada de um modo bastante distinto da simples mistificação da mercadoria e a mais complicada mistificação do dinheiro. A transubstanciação, o fetichismo, está completo. (Marx, 1861, s.p.).

Este trecho já faz parte do "universo" de $O$ Capital. A teoria do fetichismo está associada à ossificação das relações sociais e se refere, explicitamente, a um processo de transubstanciação, processo este que só será explicado no primeiro capítulo da obra que doravante será analisada.

\section{O fetichismo na obra "O Capital"}

É com a teoria do fetichismo da mercadoria que Marx finda o primeiro capítulo de $O$ Capital. Neste primeiro capítulo Marx analisa, grosso modo, a mercadoria e o dinheiro, 
categorias estas que precedem, ao menos no modo de apresentação dialético da obra, a própria categoria do capital. O que está em questão neste capítulo é, portanto, a circulação simples, um tipo específico de troca de mercadorias no qual equivalente é trocado por equivalente e da troca não resulta lucro nem ganho. Este tipo de troca já existia antes do capitalismo, embora seja com o advento deste que ela se dissemina mundialmente e aumenta de importância.

Pode-se apresentar o primeiro capítulo de O Capital como a tentativa de responder a questão: como é possível trocar duas coisas qualitativamente diferentes como se fossem equivalentes, isto é, quantitativamente iguais? A resposta a esta questão perpassa cinco etapas. $\mathrm{Na}$ primeira, percebe-se que sob a aparente diferença radical das mercadorias entre si subjaz uma propriedade comum a todas, a saber, o fato de serem todas elas criadas por trabalho humano. Eis a pista, portanto, para se descobrir como equipará-las. Ao trocarem mercadorias os homens estão trocando entre si os produtos dos seus trabalhos. Mas como medir este trabalho? Os homens medem-no pelo tempo, única maneira possível de mensurar seu dispêndio de energia. Na troca de mercadorias, então, o que os homens fazem é trocar montantes iguais de tempo de trabalho, sendo esta a segunda etapa da argumentação marxiana. Estes dois pontos já haviam sido, antes de Marx, plenamente desenvolvidos por economistas como Adam Smith e David Ricardo. A partir do terceiro ponto, porém, Marx começa a ser "original". Assim como as mercadorias diferem qualitativamente entre si, também os distintos trabalhos possuem poucas coisas em comum. Como equiparar entre si, como se fossem iguais, atividades que são completamente desiguais? Marx percebe que, no intercâmbio mercantil, o trabalho é abstraído de suas propriedades materiais para ser considerado como uma atividade abstrata, mero dispêndio de energia física, sem importar que coisas este dispêndio transforma. O terceiro ponto é, portanto, que aquilo que é mensurado e intercambiado é tempo de trabalho abstrato, indiferenciado. Mas isto ainda não resolve as sutilezas desta árdua questão. Mesmo concedendo os passos até aqui perpassados, resta o fato de que há trabalhadores que são mais ágeis, outros que são mais lentos, há terras que são mais férteis e outras quase estéreis, e o produto da terra estéril ou do trabalhador lento não vale mais, por nele estar contido mais tempo de trabalho, do que o mesmo produto do trabalhador ágil e da terra fértil. O tempo de trabalho medido em cada mercadoria e trocado por outra não é, assim, o de cada trabalhador individual, mas sim o tempo médio que, em uma sociedade, sob um determinado nível de evolução técnica dos meios de produção, demora-se para produzir a mercadoria que será intercambiada. Quando a questão parece encaminhar-se a bom termo, 
contudo, um novo golpe a espreita. Ainda que concedido os quatro pontos preliminares, resta a observação de que as mercadorias não são trocadas unicamente conforme o tempo de trabalho socialmente necessário despendido na confecção delas. Há trabalhos bem remunerados, outros miseravelmente pagos. A proporção da troca de tempo de trabalho muito raramente obedece a razão um por um. Que razão segue então? “As diversas proporções em que os diversos tipos de trabalho são reduzidos a trabalho simples, como a sua unidade de medida, estabelecem-se por um processo social às costas dos produtores, e parecem a eles daí dados pelo costume" (Marx, 2006, p. 28). Ora, depois de tanto esforço para chegar a um fundamento que permite a equiparação das distintas mercadorias parece desanimador a conclusão de que aquilo que define a razão pela qual elas são trocadas é um "processo social às costas dos produtores", um costume sem fundamento. ${ }^{10}$

Mas o intercâmbio de mercadorias, este "costume" das sociedades ocidentais, só é possível porque os homens tratam as coisas, se relacionam com os frutos dos seus trabalhos, como se estes portassem uma objetividade, como se cristalizassem em seu próprio corpo a quantia específica de tempo de trabalho que foi neles despendido. Deste modo, um produto qualquer do trabalho humano é contabilizado como "x horas de trabalho", ou, em uma forma mais desenvolvida, vale tanto de dinheiro. A mercadoria passa a ter assim uma dupla existência, uma no mundo concreto, no qual ela é um produto como qualquer outro, podendo ser utilizado para algum fim, deteriorando-se com o passar do tempo, etc. (dimensão correspondente ao seu valor de uso); e outra no "mundo das mercadorias", um mundo no qual os homens não são mais do que os veículos, os suportes, que conduzem estas mercadorias ao mercado, mercado este no qual estas mesmas mercadorias se relacionarão de forma quase autônoma, uma vez que são dotadas de uma objetividade numérica que expressa a medida de sua relação com as demais; um mundo no qual as coisas não perecem e só servem para fins de intercâmbio (dimensão correspondente ao valor de troca). Jappe observa que:

\footnotetext{
$\mathrm{Na}$ sociedade mercantil, cada coisa tem uma dupla existência, enquanto realidade concreta e enquanto quantidade de trabalho abstrato. É este segundo modo de existência que se exprime no dinheiro, que merece portanto ser chamado abstração real principal. Uma coisa 'é' uma camisa ou uma ida ao cinema e 'é' ao mesmo tempo 10 ou 20 Euros. Essa qualidade do dinheiro não pode ser comparada com nenhuma outra coisa; ela situase para lá da dicotomia tradicional entre o ser e o pensamento, dicotomia para a qual uma coisa ou existe somente na cabeça, sendo pois imaginária - é esse o sentido habitual do termo abstração -, ou, pelo contrário, é efetivamente real, material, empírica. (Jappe, 2006, p. 40)
} 
Esta dupla existência do dinheiro, mas que não é mais do que a dupla existência da mercadoria (e também, como adiante se verá, do capital), diferencia a mercadoria do restante das coisas mundanas, a torna única em sua estranheza, sua bizarrice. Em um trecho da primeira edição de $O$ Capital - trecho este que será suprimido na segunda edição, na qual Marx reescreve todo o primeiro capítulo - o autor diz, se referindo à aparição do dinheiro:

\footnotetext{
É como se ademais e aparte dos leões, tigres, lebres e de todos os restantes animais reais, que agrupados conformam os diversos gêneros, espécies, subespécies, famílias, et cetera, do reino animal, existisse também o animal, a encarnação individual de todo o gênero animal. (Marx, 2004, p. 998)
}

O específico do dinheiro, conforme a citação acima, é existir tanto como gênero quanto como espécie, concomitantemente. $\mathrm{O}$ dinheiro é tanto uma mercadoria singular, que se relaciona com as demais no mercado, no ato do intercâmbio, quanto o equivalente geral, a simples encarnação do gênero valor, valor que é uma propriedade compartilhada por todas as mercadorias e por nada mais. O específico do dinheiro, contudo, é ele ser apenas valor de troca, ele não tem a dimensão de valor de uso, como todas as restantes mercadorias. Deste modo, se cada mercadoria possui valor, sendo uma espécie partícipe deste "gênero", o dinheiro é valor, a sua encarnação direta.

"O enigma do fetiche do dinheiro", diz Marx, "é, portanto, apenas o enigma do fetiche da mercadoria, tornado visível e ofuscante" (Marx, 1996, p. 217). Isto é, esta estranheza que se manifesta claramente no dinheiro, o fato de este ser um objeto que porta uma determinada quantia de tempo de trabalho, sem outra finalidade senão a de facilitar o intercâmbio mercantil, é já uma estranheza que está contida em cada mercadoria singular. A mercadoria, e nisto ela se distingue do mero produto do trabalho que não é trocado, possui uma dupla existência: por um lado, é o objeto concreto, algo útil que é de alguma forma consumido, sensível, físico, palpável; por outro, é um objeto abstrato, um receptáculo que corporifica um determinado tempo de trabalho, algo impossível de se perceber por meio dos sentidos, metafísico, impalpável.

Destarte, é duplo o aspecto pelo qual a mercadoria, o dinheiro e o capital são categorias fetichistas. Por um lado, neles ocorre o misterioso ato da transubstanciação: o trabalho já realizado, despendido na transformação da matéria, se cristaliza a si mesmo no objeto que fabrica. ${ }^{11}$ Assim uma mesa, por exemplo, em uma sociedade mercantil não é apenas um objeto em torno da qual as pessoas sentam, mas também a encarnação de uma determinada quantia de 
tempo de trabalho, coisificadas no valor que compõe seu preço. Marx não está, obviamente, dizendo que as coisas já foram dadas ao homem prontas ou que este não labutou penosamente na transformação de uma matéria bruta em algo útil para ele. O que ele diz é apenas que a crença de que este trabalho se corporifica, se transubstancializa, na mercadoria é um misticismo, consiste em um pensamento mágico, irracional. O trabalho gasto desaparece, nada mais; o que fica é apenas a matéria bruta transformada.

Por outro lado, mas decorrente do primeiro aspecto, é que os únicos objetos que participam de dois mundos concomitantemente, caso da mercadoria, mas também dos talismãs e outros objetos divinificados, são os fetiches. Tal como para o verdadeiro católico a hóstia não apenas é um insosso pão ázimo, mas, após a consagração, também o corpo de cristo (e leia-se, literalmente o corpo de cristo), para o indivíduo partícipe das sociedades mercantis a mercadoria é tanto um determinado objeto físico, sensível, quanto a objetificação de um trabalho já passado e, portanto, metafísico, suprassensível. A natureza dos objetos fetiche é ser tanto um objeto determinado, concreto, quanto, ao mesmo tempo, algo distinto deste que é aí "encarnado"; este pode ser um deus, cristo, um espírito qualquer ou, neste caso específico, o trabalho passado.

\section{Mercadoria, dinheiro, capital}

Como já dito antes, o termo fetiche acompanha, em $O$ Capital, três categorias: a mercadoria, o dinheiro e o capital. ${ }^{12}$ Mercadoria é todo fruto do trabalho humano que intencional ou acidentalmente é trocado como equivalente por outro. ${ }^{13}$ Dinheiro é o equivalente geral das mercadorias, a encarnação direta do valor. Capital, por fim, é tanto dinheiro quanto mercadoria, é, na verdade, um incessante processo no qual dinheiro torna-se mercadorias para depois voltar a ser dinheiro, mas em um montante maior; é valor em perpétuo processo de engrandecimento. $\mathrm{O}$ que as três categorias têm em comum? O fato de serem encarnações do valor. Valor é o tempo de trabalho abstrato socialmente necessário despendido na confecção do objeto que o contém. Manifesta-se sempre no valor de troca deste objeto em questão, seja mercadoria, dinheiro ou capital. Separa-se da dimensão do valor de uso na categoria do dinheiro, e ganha a qualidade mágica da automultiplicação na categoria do capital. Por portarem valor, estas três categorias têm exatamente as duas características do fetichismo: nelas o trabalho humano abstrato está transubstanciado, e elas existem concomitantemente no "mundo concreto" e no "mundo das 
mercadorias", são ao mesmo tempo um objeto particular e potencialmente vários outros, existem enquanto algo qualitativo singular mas são a qualquer momento traduzíveis a uma pura quantidade.

O papel do fetichismo, na arquitetônica de $O$ Capital, é central. Ele aparece logo no início do livro, na análise da mercadoria, quando se começa a falar de um processo que se desenvolve às costas dos produtores, processo no qual eles tomam parte, mas do qual não têm consciência. Este processo, que nada mais é do que o desenvolvimento da própria categoria do capital, surge precisamente por meio da reificação das relações sociais, reificação esta que se dá pela objetificação fetichista do trabalho abstrato despedido nas mercadorias. Este processo - processo que é feito pelos homens, mas do qual eles não têm controle, não dominam, e pelo qual os próprios homens acabam sendo dominados - faz da sociedade capitalista mais uma sociedade "opaca", tal como as medievais, mas sua "opacidade" não se deve ao vínculo religioso que a forma, mas sim ao vínculo mercantil. ${ }^{14}$

A principal consequência prática desta opacidade social é que há uma inversão da finalidade da produção. Se os homens até então, de modo geral, trabalharam fabricando produtos visando ao seu consumo (isto é, visando ao valor de uso; que criassem também valor de troca era algo quase acidental), no capitalismo, e esta é uma das suas características específicas, a finalidade da produção é, em primeiro lugar, a criação de mais valor (ou seja, valor de troca, que produzam ao mesmo tempo valor de uso é contingente, casual). Muito embora o trabalhador, parte integrante do sistema produtivo, participe deste processo visando à sua subsistência, o consumo, ele produz, mesmo se um serviço, algo que resultará, ao dono do capital, em um maior montante de dinheiro. O capitalista produtivo não decide fabricar calçados ou armamentos por achar que o mundo carece destes produtos, sua decisão, grosso modo, decorre daquele setor que dará melhores retornos financeiros (embora existam, em algum grau, fatores morais que devam ser levados em conta nas escolhas deste tipo). O acionista não aplicaria o capital em uma empresa que desse à necessidade do consumidor prioridade ante sua própria sede de lucro.

\section{Capitalismo, religião e "opacidade" social}

É por uma necessidade intrínseca de seu objeto de estudo, o capital, que Marx retoma a temática de um de seus primeiros textos de juventude, a saber, a crítica da religião na Introdução 
à crítica da filosofia do direito de Hegel. Lá, Marx fala que "a crítica da religião é o pressuposto de toda crítica" (Marx, 2005, p. 145) e diz que "este Estado e esta sociedade produzem a religião, uma consciência invertida do mundo, por que eles são um mundo invertido" (idem, ibidem), argumenta, enfim, que é preciso passar da crítica da religião para a crítica do direito e da política. Aqui, mais de vinte anos depois, o caminho como que se inverte, é preciso passar da crítica da economia para a crítica da religião, porque a própria economia tem um cerne religioso. Quando analisa a troca mercantil, Marx diz:

\footnotetext{
É apenas a relação social determinada dos próprios homens que assume aqui a forma fantasmagórica de uma relação entre coisas. Para encontrar uma analogia, daí devemos escapar para a região nebulosa do mundo religioso. Aqui os produtos da cabeça humana parecem dotados de vida própria relacionando-se uns com os outros e com os homens em figuras autônomas. Assim se passa no mundo das mercadorias com os produtos da mão humana. Isto eu chamo de fetichismo, que adere aos produtos do trabalho tão logo eles são produzidos como mercadorias, e que é inseparável, portanto, da produção de mercadorias. (Marx, 2006, p. 69-70)
}

E depois, em um trecho do vigésimo terceiro capítulo, Marx volta a fazer a mesma analogia, dizendo que "assim como na religião o ser humano é dominado pela obra de sua própria cabeça, assim, na produção capitalista, ele o é pela obra de sua própria mão" (Marx, 1996, p. 253). A semelhança destas duas formas de dominação é que em ambas os homens são dominados por produtos que eles próprios criam, mas estes produtos assumem, frente aos homens, uma objetividade aparente, uma existência aparentemente autônoma, e por este motivo não são controlados por seus criadores. ${ }^{15}$ Aliás, é exatamente o contrário que ocorre, uma vez que os homens são obrigados a aceitar os ditames, sejam dos deuses, sejam das mercadorias, como ordens superiores ou naturais, frente às quais a desobediência seria insensatez (e, na medida em que estas relações se objetivam nas instituições e costumes, não somente seria como efetivamente é insensatez).

A crítica ao capitalismo se torna assim semelhante à crítica à religião e à superstição, pois em todos estes casos as crenças subjetivas dos homens, que se objetivam em instituições e mesmo em costumes, impedem que estes tenham uma relação racional com o mundo, relação esta que faria dos homens seres autônomos, isto é, criadores conscientes de seu mundo social circundante. O que há de específico na crítica de Marx à modernidade, como já apontado no começo deste artigo, é o entrelaçamento entre aquilo que se poderia chamar, meio weberianamente, de secularização, desencantamento ou apenas racionalização do mundo, na 
medida em que passam a ser exigidas justificações não religiosas para o ordenamento social, com um processo contrário e concomitante de reencantamento, fetichização ou irracionalização do mundo, visto que cada vez mais as relações econômicas se tornam objetivas e todo poderosas. $\mathrm{O}$ resultado é que por isso a própria modernização encontra-se bloqueada, recai novamente na superstição ao invés de emancipar-se dela. ${ }^{16}$

\title{
Conclusão
}

É na seção na qual se analisa o fetichismo da mercadoria que se encontra a melhor descrição daquilo que Marx imagina ser a sociedade comunista:

\begin{abstract}
Imaginemos, por fim, para variar, uma associação de homens livres, que trabalham com meios de produção comunitários e despendem conscientemente suas muitas forças de trabalho individuais como uma forma de trabalho social. (...) O produto conjunto da associação é um produto social. Uma parte desse produto servirá novamente como meio de produção. Ele permanece social. Mas uma outra parte será gasta como meio de vida pelos membros da associação. Deve ser dividida entre eles, portanto. O tipo dessa divisão mudará com o próprio tipo particular de organismo de produção social e o correspondente nível de desenvolvimento social dos produtores. (...) As referências sociais das pessoas a seus trabalhos e a seus produtos de trabalho permanecem aqui transparentes, tanto na produção quanto na distribuição. (Marx, 2006, p.78-9)
\end{abstract}

Esta descrição surge justamente como exemplificação de uma sociedade não fetichista, uma sociedade, portanto, na qual são abolidas as categorias intrinsecamente fetichistas, a saber, a mercadoria, o dinheiro e o capital. O que se abole, assim, é o próprio valor como forma de mediação social; de modo que o vínculo social, a relação entre os produtores associados, passa a ser "transparente", isto é, conhecida por eles. É, sem sombra de dúvida, uma imensa mudança na organização social, a tal ponto que chega a ser difícil imaginar como seria possível um mundo no qual não existissem mercadorias e dinheiro, no qual, portanto, não há troca de equivalentes. Mas a tentativa pode ser empreendida. Marx rechaça qualquer possibilidade de um retorno a algum nostálgico comunismo primitivo ou algo similar. A modernidade conta com um imenso progresso nas forças produtivas, progresso este que faz com que menos trabalho, menos esforço físico, resulte em um montante maior de produtos. Este progresso decorre, em grande parte, da combinação de um grande número de trabalhadores em um processo de fabricação comum, que cria uma acentuada divisão do trabalho e permite o uso de maquinarias caras, as quais só são viáveis em casos de grandes produções. Deste modo o trabalho social, característico do ethic@-Florianópolis, v. 11,n.1,p.141-158 Jun.2012. 
capitalismo, tem grandes vantagens sobre o individual, comum nas formas pré-capitalistas de organização social, e deveria ser mantido em uma possível sociedade comunista. O que se abole é a propriedade privada dos meios de produção, que passam a ser propriedade comum dos trabalhadores associados. O montante de produtos do processo de trabalho deixa de ser propriedade privada do capitalista para se tornar também uma propriedade comum, que será então distribuída conforme a decisão dos produtores reunidos. Como? Talvez mediante o próprio tempo de trabalho despendido, algo que Marx dá como possibilidade em tal análise. Mas este tempo despendido não passa, de modo algum, a ser visto como uma propriedade das coisas, nem é quantificado em um valor autônomo, existente em si. Ele é apenas um acordo entre os produtores, que podem revogá-lo a qualquer momento, pois o controlam conscientemente. Os produtores tornam-se assim senhores de seu processo de trabalho, usando-o para alcançar o necessário a uma vida autônoma; ao invés de, por meio de sua própria cegueira, causada pelo valor como forma de mediação social, serem usados pelo seu próprio meio de produção com a finalidade de produzir um montante cada vez maior de valor. Assim:

\footnotetext{
O reflexo religioso do mundo efetivo só pode desaparecer, em geral, quando as relações no mecanismo da vida prática cotidiana se apresentarem para os homens diariamente como referências transparentes e racionais de uns com os outros e com a natureza. A figura do processo de vida social, isto é, do processo de produção material, despirá o seu véu de névoa mística apenas quando se colocar como produto de homens livremente sociabilizados e sob seu controle consciente e planificado. (Marx, 2006, p. 80)
}

Somente aí estaria superado o fetichismo da mercadoria, somente então o mundo estaria despido de sua névoa mística e os homens poderiam, finalmente, relacionar-se de um modo racional, autônomo. Fariam, enfim, seu mundo social circundante. 


\section{Notas}

${ }^{1}$ Doutorando em Filosofia na Universidade Federal de Santa Catarina e bolsista CAPES.

${ }^{2}$ Althusser, no prefácio que escreveu ao primeiro volume da tradução francesa de $O$ Capital, sugere que o leitor comece o livro pela segunda seção da obra. A leitura da primeira seção deveria, para este autor, ser uma tarefa empreendida somente após a conclusão do livro, e mesmo assim com extrema cautela, uma vez que, em sua opinião, estão imiscuídas aí certas confusões hegelianas. Cf. Althusser, 1971, p. 81-92.

${ }^{3}$ O termo "fetichismo", que já aparece nas primeiras obras de Marx, só torna-se uma teoria nos escritos preparatórios a $O$ Capital, como adiante argumentarei.

${ }^{4}$ Mesmo o meticuloso comentário ao primeiro livro de $O$ Capital de autoria de David Harvey resume a análise do fetichismo da mercadoria com a afirmação: "Ao introduzir o conceito de fetichismo, Marx mostra como o valor naturalizado da economia política clássica dita a norma; nós excluímos as possibilidades revolucionárias se seguirmos esta norma cegamente e repetirmos o fetichismo da mercadoria. Nossa tarefa é questioná-lo." (Harvey, 2010, p. 46).

${ }^{5}$ Cito novamente Harvey: "o uso de Marx deste termo [fetichismo] é técnico e muito diferente dos outros usos comuns" (Harvey, 2010, p. 41).

${ }^{6}$ Iacono já aponta para o uso reflexivo com o qual tanto Marx quanto, posteriormente, Freud utilizaram tal conceito: "Entre todos os pensadores que discutiram o conceito de fetichismo, Marx e Freud se distinguem por modificar o contexto no qual o conceito nasceu e se desenvolveu. (...) A mudança operada por Marx e Freud consiste justamente em que o conceito de fetichismo é aplicado à análise de fenômenos (a mercadoria, a perversão sexual) próprios da sociedade a qual eles mesmos pertencem e da qual eles são observadores internos" (Iacono, 1992, p. 74).

${ }^{7}$ Sobre a relação entre romantismo e política conferir Löwy e Sayre, Romantismo e política, 1993.

${ }^{8}$ Algo certamente já esboçado tanto por Hegel quanto pelos jovens hegelianos de esquerda mas ainda não plenamente desenvolvido. O fato da crítica dos jovens hegelianos ser principalmente voltada à religião, algo que representa o ancien régime, não é sem consequências. A novidade de Marx é que a crítica tem por objeto o comércio, símbolo da modernidade, que segundo o autor está imiscuído com elementos supersticiosos, fazendo com que haja uma continuação da sociedade antiga na nova. A crítica ao comércio e ao dinheiro já está presente até mesmo na antiguidade; a novidade marxiana é que tal crítica não se baseia na tradição e nos costumes nem apela à natureza humana, mas é baseada na razão, no esclarecimento, e apela unicamente para uma maior emancipação e autonomia, para uma maior modernidade.

${ }^{9}$ Artous é um dos raros comentadores a perceber esta ambiguidade: "O fenômeno do fetichismo não depende de uma simples ilusão de consciência - individual ou coletiva -, não remete somente à aparência das relações sociais, à superfície das coisas, ele traduz o modo de existência das relações de produção capitalistas, sua forma social objetiva" (Artous, 2006, p. 21).

${ }^{10}$ Concordo com a observação de Fredric Jameson de que desta forma a primeira parte de $O$ Capital (que consiste nos três primeiros capítulos da obra) "pode ser entendida como um ataque generalizado à ideologia do mercado, ou, se preferires, como uma crítica fundamental do conceito de troca e, na verdade, da própria equação de identidade como tal" (Jameson, 2011, p. 17).

${ }^{11}$ O próprio Marx utiliza, em O Capital, duas vezes o termo transubstanciação [Transsubstantiation]: "Portanto, para exercer praticamente a ação de valor de troca, a mercadoria tem de desfazer-se de seu corpo natural, transformar-se de ouro imaginário em ouro real, ainda que essa transubstanciação lhe seja mais 'árdua' do que ao 'conceito' hegeliano a transição da necessidade para a liberdade, ou a uma lagosta o romper de sua casca” (Marx, 1996, p. 226) e "A divisão do trabalho transforma o produto do trabalho em mercadoria, tornando, com isso, necessária sua

ethic@-Florianópolis, v. 11,n.1,p.141-158 Jun.2012. 
transformação em dinheiro. Ao mesmo tempo, ela torna aleatório o sucesso dessa transubstanciação" (Marx, 1996, p. 231).

${ }^{12}$ Marx só se refere explicitamente ao fetichismo do capital no terceiro livro de $O$ Capital (enquanto trata a mercadoria e o dinheiro como objetos fetiche já no primeiro), mais especificamente quando trata do capital portador de juros, no qual o fetichismo está completo por não mais precisar da mediação da mercadoria para se autovalorizar (cf. Marx, 1988, capítulos 24 e 48).

${ }^{13}$ Aquilo que não é trocado, e nem fabricado com tal intenção, não possui valor de troca e não pode ser considerado mercadoria. Algo que é trocado, mas sem a intenção de equivalência, como na troca de dádivas ou mesmo de presentes tampouco possui valor de troca e, portanto, também não é mercadoria.

${ }^{14}$ Sobre o conceito de opacidade social, cf. Artous, 2006.

${ }^{15}$ Artous observa que: “As 'figuras autônomas' que povoam o mundo religioso têm, como formas de representação coletiva, uma eficácia social, mas, contrariamente aos produtos do trabalho, não têm uma objetividade social similar àquela das mercadorias; para Marx os deuses jamais existiram. A mercadoria, porém, que circula e se troca, tem uma materialidade, é uma relação social objetiva e não o produto de uma simples crença, de uma simples ilusão de consciência" (Artous, 2006, p. 31). Isto diferencia, certamente, a mercadoria frente às religiões, como afirma Artous, mas somente frente às religiões não fetichistas. Religiões fetichistas, tal como a católica, objetivam seus objetos de crença em artefatos concretos, materialmente existentes, caso da hóstia. Obviamente o papel da hóstia e da mercadoria são completamente distintos, embora entre eles exista uma profunda analogia.

${ }^{16}$ A semelhança com o argumento de Adorno e Horkheimer - que, na Dialética do Esclarecimento falam de um entrelaçamento entre razão e mito, entrelaçamento este que é crucial para a compreensão da modernidade e que termina, por sinal, em uma regressão à mitologia por uma falta de autorreflexão da própria razão - é profunda, embora os dois autores frankfurtianos pouco percebam esta consequência do conceito marxiano de fetichismo, o qual interpretam, usualmente, como simples adoração, como transformação de um mero meio em fim. 


\section{Referências Bibliográficas}

ADORNO, Theodor e HORKHEIMER, Max. Dialética do Esclarecimento.Tradução de Guido de Almeida. Rio de Janeiro: Jorge Zahar Editor, 1985.

ALTHUSSER, Louis. Lenin and philosophy and other essays. New York and London: Monthly Review Press, 1971.

ARTOUS, Antoine. Le fétichisme chez Marx. Paris: Éditions Syllepse, 2006.

HARVEY, David. A companion to Marx's Capital. London and New York: Verso, 2010.

IACONO, Alfonso. Le Fétichisme: histoire d'un concept. Paris: P.U.F., 1992.

JAMESON, Fredric. Representing Capital. London and New York: Verso, 2011.

JAPPE, Anselm. As aventuras da mercadoria. Tradução de José Miranda Justo. Lisboa: Antígona, 2006.

LÖWY, Michael e SAYRE, Robert. Romantismo e política. Rio de Janeiro: Paz e Terra, 1993.

MARX, Karl. Manuscritos econômico-filosóficos. Tradução de Jesus Ranieri. São Paulo: Boitempo, 2004.

Debates on the law on thefts of wood. <http://www.marxists.org/archive/marx/ works/1842/10/25.htm>, acesso em Setembro de 2011. 1842.

. Introdução à crítica da filosofia do direito de Hegel. In: MARX, Karl. Crítica da filosofia do direio de Hegel. Tradução de Rubens Enderle e Leonardo de Deus. São Paulo: Boitempo, 2005

. Grundrisse. Tradução de Mauro Duayer e Nélio Schneider. São Paulo: Boitempo; Rio de Janeiro: Ed. UFRJ 2011.

. Para a crítica da economia política. Tradução de Edgard Malagodi. São Paulo: Abril Cultural, 1982.

Theorien über den Mehrwert. Dritter Teil. <http://www.dearchiv.de /php/dok.php?archiv=mew\&brett=MEW263\&fn=BEI_472.263\&menu=mewinh $>$, acesso em Setembro de 2011. 1861.

. A mercadoria. Tradução de Jorge Grespan. São Paulo: Ática, 2006.

. O Capital. Livro I, dois volumes. Tradução de Regis Barbosa e Flávio Kothe. São Paulo: Nova Cultural, 1996. 
. O Capital. Livro III, dois volumes. Tradução de Regis Barbosa e Flávio Kothe. São Paulo: Nova Cultural, 1988.

. El Capital. Tomo I, terceiro volume. Tradução de Pedro Scaron. Buenos Aires: Siglo XXI, 2004.

ROBERT, P. Le Petit Robert. Paris: Ed. Le Petit Robert, 2009. 